\title{
Root uptake, storage and remobilisation of autumn applied nitrogen to kiwifruit (Actinidia deliciosa) vines
}

\author{
Massimo TAgLiAvini ${ }^{\mathrm{a} *}$, Paolo InGLESE ${ }^{\mathrm{b}}$, Adamo D. RombOLA ${ }^{\mathrm{a}}$ \\ ${ }^{a}$ Dipartimento di Colture Arboree, Università di Bologna, Via F. Re 6, 40126 Bologna, Italy \\ ${ }^{\mathrm{b}}$ Istituto di Coltivazioni Arboree, Università di Palermo, Viale delle Scienze 11, 90128 Palermo, Italy
}

(Received 18 June 1999; revised 10 September 1999; accepted 13 September 1999)

\begin{abstract}
Root uptake, partitioning, storage and remobilisation of nitrogen $(\mathrm{N})$ supplied to the roots of young, fruit bearing, "Hayward" kiwifruit potted plants were studied. Two rates of ${ }^{15} \mathrm{~N}$ - enriched ammoniumnitrate $[3.3 \mathrm{~g}(\mathrm{LN})$ and $10.0 \mathrm{~g}(\mathrm{HN}) \mathrm{N} /$ plant] were supplied one month before fruit harvest. Kiwifruits took up $44-68 \%$ of autumn supplied ${ }^{15} \mathrm{~N}$ that was mainly stored in the root system (61\%). Fertiliser $\mathrm{N}$ also accounted for some $22 \%$ and $36 \%$ of total $\mathrm{N}$ recovered in fruits for $\mathrm{LN}$ and $\mathrm{HN}$ plants, respectively. Leaves retained most of the labelled $\mathrm{N}$ during senescence and only a $23 \%$ of autumn $\mathrm{N}$ was withdrawn to perennial organs. Autumn supplied ${ }^{15} \mathrm{~N}$ was remobilised in spring to support the early shoot growth, and the extent of remobilisation to leaves and fruits depended upon the fertiliser rate. Newly developing shoots contained $31 \%$ of the total labelled $\mathrm{N}$ stored in winter.
\end{abstract}

fruit / kiwifruit / nitrogen / remobilisation / root uptake / storage

Résumé - Absorption racinaire, stockage et remobilisation de l'azote appliqué à l'automne sur des kiwis (Actinidia deliciosa). L'absorption racinaire, la subdivision, la conservation, et la redistribution de l'azote au niveau des racines ont été étudiées sur des jeunes plantes de kiwi cv «Hayward», portant des fruits et cultivés en pots. Deux rations de nitrate d'ammonium enrichi en ${ }^{15} \mathrm{~N}$ [3,3 $\mathrm{g}(\mathrm{LN})$ et $10,0 \mathrm{~g}(\mathrm{HN}) \mathrm{N}$ par plante] ont été distribuées 1 mois avant la récolte des fruits. Les fruits de kiwi ont absorbé $44-68 \%$ du ${ }^{15} \mathrm{~N}$ fourni à l'automne,

Communicated by Peter Millard (Aberdeen, UK)

* Correspondence and reprints

mtaglia@agrsci.unibo.it 
qui a été stocké principalement dans le système racinaire $(61 \%)$. Le ${ }^{15} \mathrm{~N}$ a représenté 22 et $36 \%$ respectivement de l'azote total contenu dans les fruits des plantes LN et HN. Les feuilles ont retenu la plus grande partie de l'azote marqué au cours de la sénescence et $23 \%$ seulement de l'azote d'automne est resté dans les organes pérennes. Le ${ }^{15} \mathrm{~N}$ fourni à l'automne a été remobilisé au printemps pour la croissance des jeunes pousses et le degré de remobilisation dans les fleurs et les fruits a été fonction de la quantité de fertilisant. Les nouvelles pousses contenaient $31 \%$ de l'azote total marqué stocké durant l'hiver.

\section{fruit / kiwi / azote / redistribution / absorption racinaire / conservation}

\section{Introduction}

Kiwifruit (Actinidia deliciosa (A. Chev.) C.F. Liang et A.R. Ferguson var. deliciosa) is a perennial fruiting crop with a large seasonal $\mathrm{N}$ demand, with two major peaks coinciding with bud swelling and the early stages of fruit growth, 2-3 weeks after fruit set $[3,17]$. In a field experiment where ${ }^{15} \mathrm{~N}$ was applied to kiwifruit vines in spring or early summer, the labelled $\mathrm{N}$ uptake was almost complete within 10 weeks from application and partitioned mainly in leaves and roots [9]. During summer and autumn the $\mathrm{N}$ requirements were met to a large extent from redistribution of the $\mathrm{N}$ previously taken up. To meet the large $\mathrm{N}$ demand that occurs in spring, $\mathrm{N}$ is both absorbed by the root and remobilised from storage pools. Estimates of the contribution of the internal cycling of $\mathrm{N}$ in this crop has been provided by Smith et al. [17] using cuttings from one year old canes grown in spring in distilled water, and by Ledgard and Brier [7] and Ledgard and Smith [8] analysing xylem sap from vines supplied with ${ }^{15} \mathrm{~N}$.

Remobilisation of $\mathrm{N}$ from storage in perennial organs contributes to a large extent to their annual $\mathrm{N}$ demand in a range of perennial fruit crops, and provides a supply of $\mathrm{N}$ for early spring vegetative and reproductive growth, before rapid root uptake occurs [10]. Sanchez et al. [15, 16] reported that some $45 \%$ of the $\mathrm{N}$ requirement for annual growth of 5-year-old pear trees comes from internal cycling, while this contribution has been estimated by $50 \%$ and $84 \%$ respectively for mature almond [21] and citrus [4] trees.
Late $\mathrm{N}$ applications result in a greater $\mathrm{N}$ partitioning to the roots as compared to $\mathrm{N}$ taken up earlier in the season in forest trees, like Acer pseudoplatanus and Fraxinus excelsior [10], as well as in fruit trees, like Prunus amygdalus [21], Prunus persica [20] and Pyrus communis [16] and enhances remobilisation to meet following spring growth.

Although $\mathrm{N}$ fertilisation in kiwifruit is often applied in one or several spring dressings, applications of relatively small amounts of $\mathrm{N}$ pre-harvest may result in an increase of $\mathrm{N}$ storage and remobilisation in spring: for this a reason such techniques have been recently adopted in some kiwifruit growing areas like the eastern Po Valley (EmiliaRomagna) of Italy.

In this study, we have applied labelled $\mathrm{N}$ to young, fruit bearing kiwifruit plants one month before fruit harvest in order to

(1) quantify the uptake and the partitioning of $\mathrm{N}$ to vegetative and reproductive organs,

(2) identify the $\mathrm{N}$ storage organs and determine their relative contribution to sustaining the $\mathrm{N}$ metabolism of new growth in spring,

(3) assess the possibility of increasing $\mathrm{N}$ remobilisation by enhancing $\mathrm{N}$ supply in autumn.

\section{Materials and methods}

In March 1997 twelve three-year old kiwifruit [Actinidia deliciosa (A. Chev.) C.F. Liang et A.R. Ferguson var. deliciosa] plants of cv. "Hayward" grafted on seedlings were planted in 24 litre pots filled with a mixture of a sand $(60 \%)$ and peat (40\%, in volume). During 1997, plants were 
bearing two fruits each and were grown in outdoors conditions receiving all essential nutrients through fertigation until the end of September. Iron-DTPA was sprayed to kiwifruit canopies to prevent the development of iron chlorosis.

On October 2, 1997, one set of eight vines (LN) was fertilised with labelled nitrogen $(\mathrm{N})$ at a rate of $3.3 \mathrm{~g} \mathrm{~N} /$ plant, while a second set of four vines $(\mathrm{HN})$ each received $10.0 \mathrm{~g}$ of labelled $\mathrm{N}$. The labelled nitrogen source was ${ }^{15} \mathrm{NH}_{4}{ }^{15} \mathrm{NO}_{3}$ with a ${ }^{15} \mathrm{~N}$ abundance of 6.0 at $\%$. The fertiliser was dissolved in water and applied to pots. Irrigation was regularly provided and no leaching occurred.

On November 3 1997, when fruits had on average 9.0 Brix degrees, they were harvested, weighed, dried at $60{ }^{\circ} \mathrm{C}$ and milled to pass a $0.5 \mathrm{~mm}$ mesh. Three leaves per plant were collected on the same date, their area measured and then they were washed, dried and milled following the same procedure as used for fruits. Leaf and fruit samples were analysed for total $\mathrm{N}$ concentration and ${ }^{15} \mathrm{~N}$ abundance by a tracer MAT continuous flow mass spectrometer (Finningan MAT, Hemel Hempstead, UK). The ${ }^{15} \mathrm{~N}$ enrichment was calculated by subtracting the background ${ }^{15} \mathrm{~N}$ abundance, equal to 0.367 at $\%$. The amount of labelled (fertiliser) $\mathrm{N}$ was calculated as described by Millard and Neilsen [11].

To assess the impact of differential $\mathrm{N}$ supply on soil $\mathrm{N}$ availability for plant uptake, soil cores form each pot were collected on November 3 and water soluble nitrate, nitrite and ammonium were extracted in distilled water $(1: 2, \mathrm{w}: \mathrm{v})$ for 1 hour with stirring, followed by filtration. Determinations were made spectroscopically using the Merck RQflex (E. Merck D 64271 Darmstadt, Germany) and specific tests (ammonium test n. 1.16892; nitrate test $\mathrm{n}$. 1.16971 and nitrite test n. 1.16973.0001). After fruit harvest and before leaf abscission started, the canopy of each single vine was covered by a net and during canopy senescence abscised leaves were collected twice a week (from November 3) until all the leaves had fallen (December 10). During leaf senescence no frost occurred. The area and mass of fallen leaves were recorded, and the samples bulked, milled and analysed for total $\mathrm{N}$ concentration and ${ }^{15} \mathrm{~N}$ abundance as before.
In January 1998 four randomly chosen LN plants were harvested. The root system was washed and plants were divided into the following organs: fine roots (less than $1 \mathrm{~mm}$ diameter), coarse roots (including the above-ground part of the rootstock), stem (including >one year-old canes), and one yearold canes (hardened shoots developed in 1997). The remaining four LN and four HN plants were transplanted, after carefully washing the root system, into similar pots filled with pure sand. During winter, plants were protected against low temperatures by inserting them in a plastic tunnel.

During the vegetative season of 1998 plants were grown outdoors and regularly fertilised with a nutrient solution, providing macronutrients at a total rate per plant of $9.0 \mathrm{~g} \mathrm{~N}, 3.0 \mathrm{~g} \mathrm{P}, 10.0 \mathrm{~g} \mathrm{~K}, 5.0 \mathrm{~g} \mathrm{Ca}$ and $1.4 \mathrm{~g} \mathrm{Mg}$. Micronutrients were also provided in adequate quantities. To assess the remobilisation of the labelled $\mathrm{N}$ supplied in the autumn of previous year the vines were destructively harvested on May 141998 and plants were divided into fine roots, coarse roots, stem and >one year-old canes, one year-old canes and shoots (new growth). All tree organs from the two harvests were dried, milled and analysed for total $\mathrm{N}$ concentration and ${ }^{15} \mathrm{~N}$ abundance as described above. The labelled $\mathrm{N}$ recovered in perennial organs and in the abscised leaves was considered as the total amount of fertiliser $\mathrm{N}$ taken up, while the labelled $\mathrm{N}$ recovered in the new growth during 1998 was considered as stored during winter and then remobilised.

The experimental design was completely randomised. Student $\mathrm{T}$ tests were used for comparing (i) amounts of labelled $\mathrm{N}$ present in each organ of LN plants in winter and in spring and (ii) amounts of labelled $\mathrm{N}$ present in LN and HN plant organs in spring. Standard errors of the means were calculated and reported. Significance of differences was considered when $\mathrm{P} \leq 0.05(*), \mathrm{P} \leq 0.01(* *)$ and $\mathrm{P}$ $\leq 0.001(* * *)$.

\section{Results}

\subsection{Nitrogen uptake and partitioning to leaves and fruits}

The two rates of labelled nitrogen applied one month before fruit harvest caused differences in the 
Table I. Leaf N concentration and content before the beginning of leaf abscission and at its end and net export of $\mathrm{N}$ out of senescing leaves.

\begin{tabular}{|c|c|c|c|c|c|c|c|c|}
\hline \multirow[t]{2}{*}{$\begin{array}{l}\text { Rate of } \mathrm{N} \\
\text { supply } \\
\text { in pre-harvest }\end{array}$} & \multicolumn{2}{|c|}{$\begin{array}{c}\text { Leaf } \mathrm{N} \\
\text { concentration } \\
\left(\mathrm{mg} \cdot \mathrm{g}^{-1}\right)\end{array}$} & \multicolumn{2}{|c|}{$\begin{array}{c}\text { Total leaf } \mathrm{N} \\
\text { content } \\
\left(\mathrm{mg} \cdot \mathrm{m}^{-2}\right)\end{array}$} & \multicolumn{2}{|c|}{$\begin{array}{c}\text { Labelled leaf } \mathrm{N} \\
\text { content } \\
\left(\mathrm{mg} \cdot \mathrm{m}^{-2}\right)\end{array}$} & \multicolumn{2}{|c|}{$\begin{array}{l}\text { Net export of } \mathrm{N} \text { out of } \\
\text { the senescing leaves } \\
\qquad\left(\mathrm{mg} \cdot \mathrm{m}^{-2}\right)\end{array}$} \\
\hline & $\begin{array}{c}\text { Before } \\
\text { abscission }\end{array}$ & $\begin{array}{l}\text { Abscised } \\
\text { leaves }\end{array}$ & $\begin{array}{c}\text { Before } \\
\text { abscission }\end{array}$ & $\begin{array}{l}\text { Abscised } \\
\text { leaves }\end{array}$ & $\begin{array}{c}\text { Before } \\
\text { abscission }\end{array}$ & $\begin{array}{l}\text { Abscised } \\
\text { leaves }\end{array}$ & Total N & $\begin{array}{c}\text { Labelled } \\
\mathrm{N}\end{array}$ \\
\hline $\mathrm{LN}$ & $20.9 \pm 0.8^{1}$ & $20.4 \pm 0.9$ & $2521 \pm 155$ & $2034 \pm 80$ & $618 \pm 56$ & $475 \pm 16$ & $487 \pm 90$ & $143 \pm 61$ \\
\hline $\mathrm{HN}$ & $25.2 \pm 1.0$ & $27.0 \pm 0.9$ & $3675 \pm 144$ & $2692 \pm 91$ & $1545 \pm 112$ & $1175 \pm 88$ & $983 \pm 69$ & $369 \pm 49$ \\
\hline Significance & $n s^{2}$ & $*$ & $* *$ & $* *$ & $* *$ & $* *$ & $* *$ & * \\
\hline
\end{tabular}

${ }^{1}$ Mean \pm SE.

$2 *, * *$ and $\mathrm{ns}=$ significance at $0.05,0.01$ level of probability and not significant.

concentration of nitrate extracted from the soil: peat mixture, averaging on Nov. $3153 \pm 17$ (SE) $\mu \mathrm{g} \cdot \mathrm{g}^{-1}$ for $\mathrm{HN}$ vines and $43 \pm 12$ (SE) $\mu \mathrm{g} \cdot \mathrm{g}^{-1}$ for $\mathrm{LN}$ vines. Soil nitrite and ammonium concentrations were negligible in both sets of plants, averaging less than $1 \mu \mathrm{g} \cdot \mathrm{g}^{-1}$. Fertilisation rate affected the uptake of nitrogen. Before leaf abscission started (Tab. I) N content was significantly higher in plants receiving $10.0 \mathrm{~g} \mathrm{~N}(\mathrm{HN})$ than in those receiving $3.3 \mathrm{~g} \mathrm{~N}(\mathrm{LN})$ each. In $\mathrm{LN}$ plants, $24 \%$ of leaf $\mathrm{N}$ before leaf senescence originated from labelled $\mathrm{N}$ uptake, while in leaves of $\mathrm{HN}$ vines the value was $42 \%$ (Tab. I). Fruits also contained significant amounts of fertiliser $\mathrm{N}$ applied one month prior their harvest (Tab. II), representing 22 and $36 \%$ of total fruit $\mathrm{N}$ content in $\mathrm{LN}$ and $\mathrm{HN}$ plants, respectively.

Nitrogen concentration in abscised leaves did not differ significantly $(\mathrm{P} \leq 0.05)$ from that in leaves before abscission (Nov. 3, Tab. I), while their $\mathrm{N}$ content was significantly lower, regardless the rate of $\mathrm{N}$ supply. Abscission rate was unaffected by treatments (data not reported in tables): about $25 \%$ of total of leaf biomass (on average $75 \mathrm{~g} /$ plant DW) abscised between November 24 and December 1 and more than $60 \%$ abscised between December 1 and December 10. Abscised leaves from HN plants contained significantly more total and labelled $\mathrm{N}$ than corresponding leaves from LN plants (Tab. I). The net export of labelled $\mathrm{N}$ from senescing leaves to perennials organs was significantly higher in $\mathrm{HN}$ than LN plants (Tab. I), a fact that resulted in dif- ferent total amounts of $\mathrm{N}$ being translocated out of the leaves in the two sets of plants. The fraction of labelled $\mathrm{N}$ remobilised during leaf senescence, however, was not affected by the rate of $\mathrm{N}$ supply and averaged $23 \%$ of the labelled $\mathrm{N}$ present before senescence started.

The amounts of labelled $\mathrm{N}$ recovered in winterharvested plants were added to those recovered in abscised leaves (404 and $1017 \mathrm{mg} / \mathrm{plant}$ in $\mathrm{LN}$ and HN plants, respectively) to quantify total fertiliser $\mathrm{N}$ uptake, which amounted to $2039 \mathrm{mg}$ by LN plants and $4226 \mathrm{mg}$ by $\mathrm{HN}$ ones.

\subsection{Nitrogen storage and remobilisation}

In winter, only LN plants were sampled for assessing the partitioning of labelled $\mathrm{N}$ and a total

Table II. Total $\mathrm{N}$ and fertiliser $\mathrm{N}$ recovered in fruits at harvest as affected by the rate of labelled $\mathrm{N}$.

\begin{tabular}{lcc}
\hline $\begin{array}{l}\text { Rate of } \\
\text { N supply in } \\
\text { pre-harvest }\end{array}$ & $\begin{array}{c}\text { Total amount of N } \\
\text { (mg/fruit) }\end{array}$ & $\begin{array}{c}\text { Amount of labelled N } \\
\text { (mg/fruit) }\end{array}$ \\
\hline LN & $125 \pm 12^{1}$ & $27 \pm 5$ \\
HN & $137 \pm 14$ & $50 \pm 11$ \\
Significance & $\mathrm{ns}^{2}$ & $*$ \\
\hline
\end{tabular}

\footnotetext{
${ }^{1}$ Mean \pm SE.

$2 *$ and ns $=$ significance at 0.05 level of probability and not significant.
} 
of $1635 \mathrm{mg} \mathrm{N}$ was recovered in the perennial organs of each plant. The fine roots contained on average $395 \mathrm{mg} \mathrm{N}$, the coarse roots $609 \mathrm{mg} \mathrm{N}$, while 323 and $308 \mathrm{mg} \mathrm{N}$ were recovered in twigs and older aerial organs (Fig. 1).

The total amount of labelled $\mathrm{N}$ recovered in $\mathrm{LN}$ vines sampled in spring (1649 $\mathrm{mg} \mathrm{N}$ ) was the same as that found in plants harvested in winter $(1635 \mathrm{mg}$ $\mathrm{N}$ ), indicating that washing the root system and transferring the plants was effective to prevent them from taking up any labelled $\mathrm{N}$ when transplanted in the new pots. In spring, $515 \mathrm{mg}$ of the labelled $\mathrm{N}$ stored in winter were remobilised to developing shoots (Fig. 1) and this accounted for $31 \%$ of the total labelled $\mathrm{N}$ in the plants. In the spring harvested plants, the amount of labelled $\mathrm{N}$ recovered in fine roots and in older aerial organs (stem and > one year-old canes), but not that contained in one yearold canes and coarse roots, was significantly less than corresponding amounts recovered in the same organs in winter (Fig. 1).

Plants supplied with the highest rate of fertiliser $\mathrm{N}$ in autumn had significantly more labelled $\mathrm{N}$ in their organs as compared with the LN plants (Tab. III). The greater labelled $\mathrm{N}$ content in HN plants was due especially to higher amounts of labelled $\mathrm{N}$ recovered in developing shoots, twigs and coarse roots. Developing shoots from HN plants, in particular, although showing similar growth (data not shown), contained almost twice the amounts of labelled $\mathrm{N}$ as compared with shoots from LN plants.
Table III. Effect of the rate of $\mathrm{N}$ fertiliser supplied in pre-harvest on the amount of $\mathrm{N}$ recovered in plant organs in spring 1998.

Amounts of labelled N Significance (mg/plant)

\begin{tabular}{lccc}
\hline ORGAN & HN Plants & LN Plants & \\
\hline Fine roots & $290 \pm 13^{1}$ & $169 \pm 17$ & $* * * 2$ \\
Coarse roots & $822 \pm 125$ & $498 \pm 17$ & $*$ \\
Stem and >one & & & \\
year- old canes & $208 \pm 16$ & $137 \pm 17$ & $*$ \\
$\begin{array}{l}\text { One year-old canes } \\
\text { Shoots }\end{array}$ & $1049 \pm 137$ & $330 \pm 99$ & $*$ \\
TOTAL & $3209 \pm 51$ & $1649 \pm 80$ & $* * *$ \\
\hline
\end{tabular}

${ }^{1}$ Mean \pm SE.

$2 *$ and $* * *=$ significance at 0.05 and 0.001 level of probability.

Regardless the N supply rate, kiwifruit vines remobilised into the developing shoots some $31-32 \%$ of the labelled $\mathrm{N}$ previously stored in winter (Tab. III).

\section{Discussion}

The annual $\mathrm{N}$ requirement of kiwifruit is relatively high [1], if compared to other perennial fruit plants. Nitrogen needs are thought to be continuous

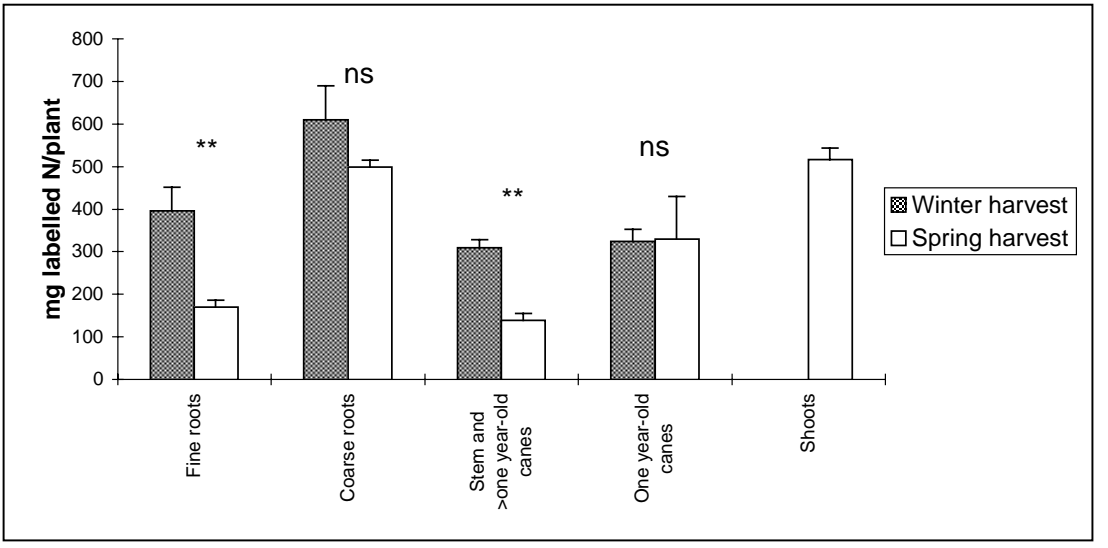

Figure 1. Within-plant distribution of labelled $\mathrm{N}$ in $\mathrm{LN}$ kiwifruit plants in winter and in spring. ** and ns indicate significance at $\mathrm{P}<0.01$ and non significance. Standard errors of the means are reported. 
throughout the long vegetative season [2,17], but assessments of nitrogen uptake by kiwifruit using ${ }^{15} \mathrm{~N}$ techniques have been made for spring and summer periods only $[8,9]$. The present study indicates that the root system of kiwifruit is highly efficient in taking up the nitrogen applied in early autumn, representing $68 \%$ of the $\mathrm{N}$ supplied to $\mathrm{LN}$ plants, and $44 \%$ to $\mathrm{HN}$ ones. Late uptake of nitrogen occurred in the absence of primary shoot growth as previously found in nectarine trees [20] and perhaps could be correlated with an enhanced photosynthate supply to the root system [6] which in kiwifruit is indicated by the increase of starch concentration in fine roots before fruit maturity [3].

This study allowed an assessment of the fate of the nitrogen taken up by the fruit of Actinidia deliciosa. Total fruit $\mathrm{N}$ content (Tab. II) at its maturity was similar to that reported by Clark and Smith [2] and by Pailly [13] for kiwifruit grown under field conditions; in our experiment, although plants were bearing only a limited number of fruits, these contained significant amounts of nitrogen derived from fertiliser. The amount of $\mathrm{N}$ available to the root system in autumn significantly affected fruit $\mathrm{N}$ content and when plants were supplied with the highest $\mathrm{N}$ rate, more than one third of total fruit $\mathrm{N}$ was derived from the root uptake in the month before their harvest. Clark and Smith [3] showed that with a generous $\mathrm{N}$ supply, fruit $\mathrm{N}$ content increased almost linearly after 8 weeks from pollination, while it has been shown that interrupting $\mathrm{N}$ supply reduced fruit $\mathrm{N}$ content in the same period [13]. Since xylem flux to fruit of Actinidia tends to be negligible after the cell division phase [5], nitrogen partitioning to fruit in the last developmental stages is almost entirely dependent upon phloem influx from the leaves [3], which at the time of fruit maturity also contained significant amounts of labelled nitrogen (Tab. I). The question to which extent the level of nitrogen in the fruit affects the storage quality of the fruit of Actinidia is still being debated: however, several authors have reported that an excessive $\mathrm{N}$ level in the vine $[1,18]$ or in the fruit $[13,14]$ increases fruit softening and rotting during storage. Therefore, to avoid excessive $\mathrm{N}$ uptake by the fruit, caution should be taken when applying $\mathrm{N}$ fertilisers before fruit harvest.
Data from the present study indicate that most $\mathrm{N}$ taken up in the autumn and early winter was partitioned to the perennial organs (Fig. 1), while 23\% was retained in the abscised leaves. This fraction is, however, considerably higher than that (10\%) reported for abscised leaves from nectarine trees grown under similar conditions and fertilised with labelled $\mathrm{N}$ in summer-autumn [20]. As shown in Table II, most $\mathrm{N}$ (73-80\%) present in the leaves at the time of fruit harvest was retained during leaf senescence and recovered in the abscised leaves. This suggests a low ability of Actinidia deliciosa to withdraw $\mathrm{N}$ in autumn from senescing leaves, as compared to other woody plants $[10,19]$. This might be explained by the fact that more than $85 \%$ of total leaf biomass abscised in a short period before December 10.

The net export of labelled nitrogen to perennial organs during leaf senescence averaged 157 and $478 \mathrm{mg} / \mathrm{plant}$ in LN and $\mathrm{HN}$ plants, respectively. Such amounts account for a small fraction (10$15 \%$ ) of total labelled $\mathrm{N}$ recovered in plants in the following spring (Tab. III). Remobilisation of leaf $\mathrm{N}$ during senescence is not the only source of $\mathrm{N}$ used to augment storage over the winter [10] as some deciduous trees can take up nitrogen in autumn, which is allocated directly to storage. Data obtained in this study suggest that root uptake must have significantly contributed directly to storage and accord with findings by Weinbaum et al. [21] for Prunus amygdalus, by Millard and Thomson [12] for Malus domestica and by Tagliavini et al. [19] for Prunus persica.

The percentage of $\mathrm{N}$ derived from fertiliser accounted for $17 \%$ of total $\mathrm{N}$ content (515 out of $2953 \mathrm{mg} /$ shoot) in shoots of LN plants and 34\% in $\mathrm{HN}$ ones (1040 out of $3024 \mathrm{mg} / \mathrm{shoot}$ ). These values likely represent an underestimate of the whole $\mathrm{N}$ remobilisation from storage as they do not take into account the remobilisation of unlabelled $\mathrm{N}$ absorbed before autumn 1997. However, the data agree with evidence provided by Ledgard and Brier [7] and by Ledgard and Smith [8], who analysed xylem sap from kiwifruit plants supplied with labelled $\mathrm{N}$ in early spring and estimated that the remobilised $\mathrm{N}$ may account for $60 \%$ of total $\mathrm{N}$ in new growth 4 weeks from bud burst, declining to 
$30 \%$ four weeks later. It appears, therefore, that the internal cycling of $\mathrm{N}$ represents a major source of $\mathrm{N}$ for shoot development of kiwifruit plants in spring.

Our data indicate that $\mathrm{N}$ fertilisation in autumn represent a powerful technique for increasing $\mathrm{N}$ storage to sustain shoot $\mathrm{N}$ metabolism in the early part of next season. Excessive $\mathrm{N}$ supply in this period, however, should be avoided as it results in a significant increase of fruit $\mathrm{N}$ content.

Acknowledgements: University of Bologna Dipartimento di Colture Arboree publication No. 1478. The authors wish to thank Dr. A. Midwood of MLURI (Aberdeen, UK) for performing the analyses of total and labelled $\mathrm{N}$ and Dr. P. Millard for revising the English text. The authors are also grateful to Mr. C. Inderst for his help in data collection and sample preparation and to Mrs. A. Guillemine for revising the French abstract.

\section{References}

[1] Buwalda J.G., Wilson G.J., Smith G.S., Littler R.A., The development and effects of nitrogen deficiency in field-grown kiwifruit (Actinidia deliciosa) vines, Plant Soil 129 (1990) 173-182.

[2] Clark C.J., Smith G.S., Seasonal, accumulation of mineral nutrients by kiwifruit, New Phytol. 108 (1988) 399-409.

[3] Clark C.J., Smith G.S., Seasonal dynamics of biomass and mineral nutrient partitioning in mature kiwifruit vines, Ann. Bot. 70 (1992) 229-237.

[4] Feigenbaum S., Bielorai H., Erner Y., Dasberg S., The fate of ${ }^{15} \mathrm{~N}$ labelled nitrogen applied to mature citrus trees, Plant Soil 97 (1987) 179-187.

[5] Ferguson I.B., The uptake and transport of calcium in the fruit tree, in: Atkinson D., Jackson J.E., Sharples R.O., Waller W.M., (Eds.), Mineral Nutrition of Fruit Tree, Butterworths, LondonBoston, 1980, pp. 183-192.

[6] Jordan M.O., Habib R., Bonafous M., Uptake and allocation of nitrogen in young peach trees as affected by the amount of photosyntates available in roots, J. Plant Nutr. 21 (1998) 2441-2454.

[7] Ledgard S.F., Brier G.J., A ${ }^{15} \mathrm{~N}$ method to quantify the sources of nitrogen for new growth of non-legumes, examined using kiwifruit, Ann. Bot. 68 (1991) 75-78.

[8] Ledgard S.F., Smith G.S., Sprosen M.S., Fate of ${ }^{15} \mathrm{~N}$-labelled nitrogen fertilizer applied to kiwifruit (Actinidia deliciosa) vines. I. ${ }^{15} \mathrm{~N}$ recovery in plant and soil, Plant Soil 147 (1992) 49-57.

[9] Ledgard S.F., Smith G.S., Fate of ${ }^{15} \mathrm{~N}-$ labelled nitrogen fertilizer applied to kiwifruit (Actinidia deliciosa) vines, II. Temporal change in ${ }^{15} \mathrm{~N}$ within vines, Plant Soil 147 (1992) 59-68.

[10] Millard P., Ecophysiology of the internal cycling of nitrogen for tree growth, Z. Pflanzenernähr. Bodenk. 159 (1996) 1-10.

[11] Millard P., Nielsen G.H., The influence of nitrogen supply on the uptake and remobilisation of stored $\mathrm{N}$ for the seasonal growth of apple trees, Ann. Bot. 63 (1989) 301-309.

[12] Millard P., Thomson C.M., The effect of the autumn senescence of leaves on the internal cycling of nitrogen for the spring growth of apples, J. Exp. Bot. 40 (1989) 1285-1289.

[13] Pailly O., Facteurs de variabilité de la qualité du Kiwi en conservation : applications agronomiques, Ph.D. thesis, Académie de Montpellier (1992).

[14] Prasad M., Spiers T.M., The effect of nutrition on the storage quality of kiwifruit (a review), Acta Hort. 297-II (1991) 579-585.

[15] Sanchez E.E., Righetti T.L., Sugar D., Lombard P.B., Recycling of nitrogen in field-grown 'Comice' pears, J. Hort. Sci. 66 (1991) 479-486.

[16] Sanchez E.E., Righetti T.L., Sugar D., Lombard P.B., Effect of timing of nitrogen application on nitrogen partitioning between vegetative, reproductive, and structural components of mature 'Comice' pears, J. Hort. Sci. 67 (1992) 51-58.

[17] Smith G.S., Clark C.J., Henderson H.V., Seasonal accumulation of mineral nutrient by kiwifruit. I. Leaves, New Phytol. 106 (1987) 81-100. 
[18] Tagliavini M., Toselli M., Marangoni B., Stampi G., Pelliconi F., Nutritional status of kiwifruit affects yield and fruit storage, Acta Hort. 383 (1995) 227-237.

[19] Tagliavini M., Millard P., Quartieri M., Storage of foliar-absorbed nitrogen and remobilization for spring growth in young nectarine (Prunus persica var. nectarina) trees, Tree Physiol. 18 (1998) 203-207.
[20] Tagliavini M., Millard P., Quartieri M., Marangoni B., Timing of nitrogen uptake affects winter storage and spring remobilisation of nitrogen in nectarine (Prunus persica var. nectarina) trees, Plant Soil 211 (1999) 149-153.

[21] Weinbaum S.A., Klein I., Broadbent F.E., Micke W.C., Muraoka T.T., Effects of time of nitrogen application and soil texture on the availability of isotopically labelled fertilizer nitrogen to reproductive and vegetative tissue of mature almond trees, J. Am Soc. Hort. Sci. 109 (1984) 526-529. 